\title{
Cafeteria diet inhibits insulin clearance by reduced insulin- degrading enzyme expression and mRNA splicing
}

\section{P Brandimarti*, J M Costa-Júnior*, S M Ferreira, A O Protzek, G J Santos, E M Carneiro, A C Boschero and L F Rezende}

Department of Structural and Functional Biology, Institute of Biology, State University of Campinas (UNICAMP), PO Box 6109, Campinas, SP, CEP 13083-865, Brazil

*(P Brandimarti and J M Costa-Júnior contributed equally to this work.)
Correspondence should be addressed to L F Rezende Email luizbio@gmail.com

\begin{abstract}
Insulin clearance plays a major role in glucose homeostasis and insulin sensitivity in physiological and/or pathological conditions, such as obesity-induced type 2 diabetes as well as diet-induced obesity. The aim of the present work was to evaluate cafeteria diet-induced obesity-induced changes in insulin clearance and to explain the mechanisms underlying these possible changes. Female Swiss mice were fed either a standard chow diet (CTL) or a cafeteria diet (CAF) for 8 weeks, after which we performed glucose tolerance tests, insulin tolerance tests, insulin dynamics, and insulin clearance tests. We then isolated pancreatic islets for ex vivo glucose-stimulated insulin secretion as well as liver, gastrocnemius, visceral adipose tissue, and hypothalamus for subsequent protein analysis by western blot and determination of mRNA levels by real-time RT-PCR. The cafeteria diet induced insulin resistance, glucose intolerance, and increased insulin secretion and total insulin content. More importantly, mice that were fed a cafeteria diet demonstrated reduced insulin clearance and decay rate as well as reduced insulin-degrading enzyme (IDE) protein and mRNA levels in liver and skeletal muscle compared with the control animals. Furthermore, the cafeteria diet reduced IDE expression and alternative splicing in the liver and skeletal muscle of mice. In conclusion, a cafeteria diet impairs glucose homeostasis by reducing insulin sensitivity, but it also reduces insulin clearance by reducing IDE expression and alternative splicing in mouse liver; however, whether this mechanism contributes to the glucose intolerance or helps to ameliorate it remains unclear.
\end{abstract}
Key Words
- cafeteria diet
- insulin-degrading enzyme
- insulin clearance
- obesity
- diabetes

Journal of Endocrinology (2013) 219, 173-182

\section{Introduction}

Type 2 diabetes is a complex illness mainly characterized by hyperglycemia, usually accompanied by pancreatic islets malfunction, and reduced insulin sensitivity, as well as lower insulin clearance.

Although hyperglycemia is one of the main elements for diagnosis of type 2 diabetes, the alterations in insulin resistance, secretion, and clearance vary according to disease development. At onset of type 2 diabetes, there is an increase in insulin resistance, coupled with increased pancreatic islet $\beta$-cell insulin secretion and reduced insulin clearance, leading to a normoglycemic/hyperinsulinemic state. Eventually, the pancreatic islet $\beta$-cells undergo a

Published by Bioscientifica Ltd. 
degenerative process that culminates with their death by apoptosis and subsequent reduction in glucose-induced insulin secretion (Chandra et al. 2001).

As for insulin clearance, it seems to be mostly controlled upon degradation by the liver and plays a critical role in glycemic control (Mckeigue et al. 1991, Kotronen et al. 2008). Also, in hepatocytes, insulin degradation is mediated primarily by the insulindegrading enzyme (IDE; Valera Mora et al. 2003).

While increased insulin secretion and reduced insulin sensitivity have been extensively described and studied in obese individuals and animals, the insulin clearance process is supposedly at least as important to obesityinduced type 2 diabetes as other causes (Butterfield 1970, Nijs et al. 1990, Kotronen et al. 2008).

Recently, these remarks have been reinforced by a series of articles showing that the reduction in insulin clearance during weight gain is probably more relevant than the increase in insulin secretion for the increased insulinemia (Erdmann et al. 2008, 2009). Moreover, insulin clearance is a highly heritable trait (Guo et al. 2012) with the highest correlation with insulinemia (Goodarzi et al. 2011).

Despite all this evidence for the importance of insulin clearance to the obesity-induced type 2 diabetes, the effect of cafeteria diet has never been described or investigated in any animal model. This dietary intervention more closely resembles Western feeding habits (Rothwell \& Stock 1979, Mittelman et al. 2000) and is clearly more efficient in inducing insulin resistance, glucose intolerance, and inflammation (Sampey et al. 2011) than the conventional lipid supplementation diet. Therefore, the aim of the present work was to investigate the possible effects of obesity-induced type 2 diabetes on insulin clearance in mice fed a cafeteria diet.

\section{Materials and methods}

\section{Reagents}

Anti-IDE and anti-GAPDH (Santa Cruz Biotechnology) primary antibodies were used for western blotting.

\section{Animals and experimental design}

Female Swiss mice that were 10-12 weeks old (Unib:SW strain) were acquired from the State University of Campinas and were maintained on a $12 \mathrm{~h}$ light: $12 \mathrm{~h}$ darkness cycle at $20-21{ }^{\circ} \mathrm{C}$ with controlled humidity during the entire experiment. The mice were fed either a standard chow diet and offered tap water and allowed to feed and drink ad libitum (control) or offered a cafeteria diet as described previously and allowed to feed ad libitum for 8 weeks (Vanzela et al. 2010). After this period, the animals were killed in a $\mathrm{CO}_{2}$-saturated atmosphere immediately followed by decapitation. The animal procedures were performed according to the guidelines of the State University of Campinas Animal Care Ethics Committee. All the experiments adhered to ACSM recommendations and were approved by the State University of Campinas Ethics Committee.

\section{Tissue samples}

Liver, gastrocnemius muscle, visceral adipose tissue, and hypothalamus samples from the Swiss mice were extracted, snap-frozen in liquid nitrogen, and stored at $-80^{\circ} \mathrm{C}$ for subsequent protein and mRNA extraction. Pancreatic islets were isolated from mice with collagenase as described previously (Rezende et al. 2009).

\section{Western blot}

Western blots were performed as described previously (Santos et al. 2011).

\section{Real-time RT-PCR}

Extracts from mouse tissues that had been previously stored as described were homogenized in TRIzol and phenol/ chloroform RNA extracted according to the manufacturer's instructions (Gibco-BRL). To evaluate mRNA levels and search for alternatively spliced transcript variants of different sizes, RT-PCR was performed using cDNAs as templates with TaqDNA polymerase (Invitrogen/Life Sciences) and corresponding primers $14 \mathrm{~F}, 15 \mathrm{a}-\mathrm{R}$ (higher IDE activity), and 15b-R (lower IDE activity) used as described previously (Kim et al. 2007, Pivovarova et al. 2009). Relative target transcript quantities were calculated from duplicate samples, and the data were normalized to the endogenous control $\beta$-actin. $\beta$-Actin F, $5^{\prime}$-AGAGGGAAATCGTGCGTGACA-3' and R, 5'-CGATAGTGATGACCTGACCGTCA-3'; IDE 14F, 5'-CCGAAGGCTTGTCTCAACTT-3'; IDE 15a-R, 5'-ATACATCCCATAGATGGTATTTTGG- ${ }^{\prime}$; and IDE $15 \mathrm{~b}-\mathrm{R}$, 5'-TGCATTCATTCCTGATGCAATGC-3'.

\section{Pancreatic islet glucose-stimulated insulin secretion}

Four batches of ten islets each were pre-incubated for $1 \mathrm{~h}$ in Krebs-Henseleit buffer solution (KHBS) containing

Published by Bioscientifica Ltd 
$0.5 \mathrm{~g} / \mathrm{l} \mathrm{BSA}$ and $2.8 \mathrm{mmol} / \mathrm{l}$ glucose and were equilibrated with $95 \% \mathrm{O}_{2}$ and $5 \% \mathrm{CO}_{2}$ at $37^{\circ} \mathrm{C}$. The media were discarded and the islets were incubated for an additional hour in $1 \mathrm{ml}$ KHBS containing 2.8, 11.2, or $22.4 \mathrm{mmol} / 1$ glucose. The supernatant was subsequently collected to evaluate insulin secretion, and the remaining islets were homogenized in an alcohol/acid solution to measure the total insulin content using a RIA.

\section{Intraperitoneal glucose tolerance test}

Swiss mice received an i.p. glucose injection $(1 \mathrm{~g} / \mathrm{kg}$ in $0.9 \%$ $\mathrm{NaCl})$ after an 8-h fast. Blood samples $(75-100 \mu \mathrm{l})$ were collected from the tail immediately before the injection and $15,30,45$, and $120 \mathrm{~min}$ following the injection to determine the concentrations of glucose and insulin. Glucose was evaluated with glucose strips on an Accu-Chek Performa II instrument (Roche), and insulin was measured using a RIA as described previously (Rezende et al. 2007).

\section{Intraperitoneal insulin tolerance test}

Non-fasted Swiss mice received an i.p. insulin injection $(1 \mathrm{U} / \mathrm{kg})$. Blood glucose was measured using test strips (Accu-Chek Performa II) at baseline ( $0 \mathrm{~min}$, before insulin administration) and 5, 10, 15, 20, and $30 \mathrm{~min}$ after the administration of insulin. Glucose measurements were then converted into natural logarithm (Ln); the slope was calculated using linear regression (time $\times \operatorname{Ln}($ glucose)) and multiplied by 100 to obtain the glucose decay constant rate during the insulin tolerance test $\left(k_{\mathrm{ITT}}\right)$ per minute $(\% / \mathrm{min})$.

\section{In vivo insulin clearance}

We evaluated the concentrations of plasma insulin in Swiss mice that had been submitted to an intraperitoneal ITT. Insulin clearance was evaluated as described previously (Ahrén et al. 2005). The constant rate for insulin disappearance (insulin decay) was calculated by first converting the insulin measurements into natural logarithm (Ln); the slope was calculated using linear regression (time $\times \operatorname{Ln}($ insulin)) and multiplied by 100 to obtain the insulin decay constant rate per minute $(\% / \mathrm{min})$. We also calculated the area under the curve (AUC) of the insulin concentrations during the experiment.

\section{Statistical analysis}

Point-to-point comparisons were performed using the ANOVA test. When the same animals were evaluated at different time points, we applied the repeated measures ANOVA test with the unpaired Tukey-Kramer post-test. The results were considered significantly different for $P<0.05$. In the RT-PCR experiments, the results were considered different only for $P<0.01$.

\section{Results}

\section{Food component intake and metabolic variables of mice fed a cafeteria diet}

Table 1 demonstrates that the cafeteria diet indeed differed from the control diet. The cafeteria diet had an approximate twofold enhancement in caloric intake that originated from the lipid content, which was fourfold increased, and carbohydrates. However, the ingestion of other dietary components remained unchanged, thus evidencing the efficiency of the dietary intervention.

As expected, the mice that were fed a cafeteria diet also had increased body and visceral fat pad weights as well as higher plasma insulin and glucose values than mice fed the control diet.

\section{Cafeteria diet-mediated effect on mouse insulin sensitivity}

Cafeteria diet-fed mice had an impaired ITT (Fig. 1A), an increased AUC during the glucose tolerance test (GTT; Fig. 1B), and reduced $k_{\text {ITT }}$ (Fig. 1C). Taken together, these alterations suggest that the cafeteria diet induced insulin resistance.

Table 1 Intake and metabolic variables. Food component intake and metabolic variables of mice fed the cafeteria diet. Energy intake was calculated based on daily food intake and nominal calorie content of each individual item in the offered diet. Values were expressed as the mean \pm s.E.M., $n=6$. NEFA, non-esterified fatty acids; TGs, triglycerides.

\begin{tabular}{|c|c|c|}
\hline & Control & Cafeteria \\
\hline Energy intake (kcal/kg per day) & $671.4 \pm 85.5$ & $1084.7 \pm 180.7 *$ \\
\hline Carbohydrate intake (g/kg per day) & $123.7 \pm 15.8$ & $157.3 \pm 11.1 *$ \\
\hline Protein intake (g/kg per day) & $35.3 \pm 4.5$ & $32.2 \pm 3.3$ \\
\hline Lipid intake (g/kg per day) & $17.7 \pm 2.3$ & $60.3 \pm 6.2^{*}$ \\
\hline Fasting insulin (pmol/l) & $0.8 \pm 0.1$ & $2.6 \pm 0.2 *$ \\
\hline Fasting glycemia $(\mathrm{mmol} / \mathrm{l})$ & $6.7 \pm 0.2$ & $8.0 \pm 0.3 *$ \\
\hline Body weight (g) & $38.8 \pm 1.0$ & $47.5 \pm 2.3^{*}$ \\
\hline Visceral fat pad weight (g) & $1.34 \pm 0.09$ & $3.15 \pm 0.74 *$ \\
\hline NEFA $(\mu \mathrm{mol} / \mathrm{l})$ & $708.6 \pm 98.6$ & $1246.9 \pm 143.1^{*}$ \\
\hline TGs (mg/dl) & $38.3 \pm 8.1$ & $56.6 \pm 7.7 *$ \\
\hline
\end{tabular}

${ }^{*} P \leq 0.05$ was significantly different from the control.

Published by Bioscientifica Ltd. 

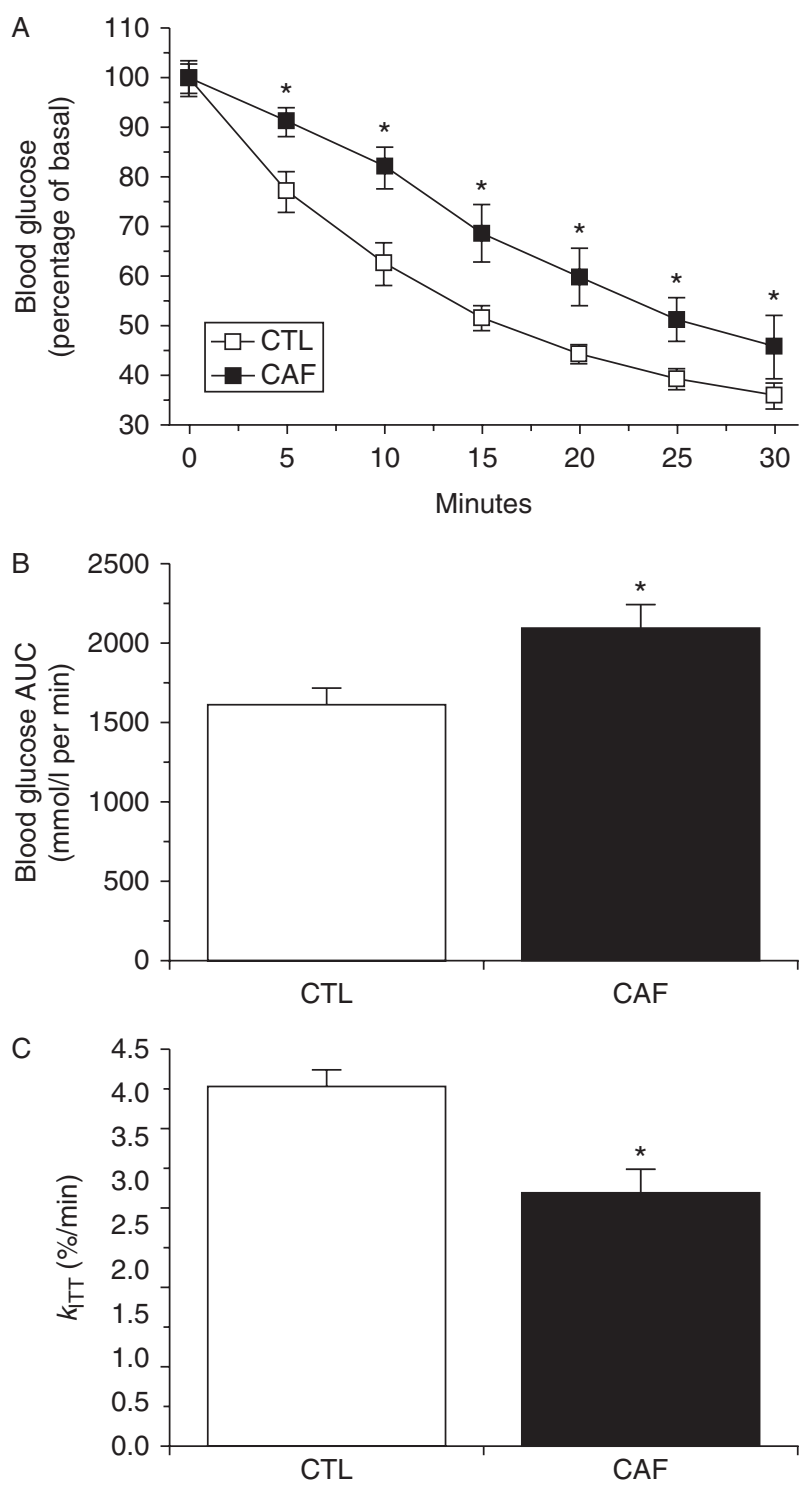

Figure 1

Cafeteria-diet-mediated effects on mouse insulin sensitivity. ITT (A), glucose AUC during the ITT (B), and $k_{1 T T}$ (C) of the control (CTL) and cafeteria diet (CAF)-fed mice. The values are expressed as the mean \pm s.E.M., $n=6$. $* P \leq 0.05$ was considered significantly different from the control.

\section{Cafeteria diet-mediated effect on glucose tolerance and insulin dynamics in mice}

Cafeteria diet-fed mice were more glucose intolerant than mice that were fed a control diet, as evidenced by the intraperitoneal GTT (Fig. 2A) and increased plasma glucose AUC during the GTT (Fig. 2B). This glucose intolerance was accompanied by drastic changes in the insulin dynamics following the glucose challenge. Plasma insulin increased faster and to a higher degree and was maintained longer in the cafeteria diet-fed mice compared with the control group (Fig. 2C), which resulted in increased exposure of these mice to insulin after the glucose challenge, as evidenced by the AUC of insulin during the GTT (Fig. 2D).

\section{Cafeteria diet-mediated effects on mouse insulin secretion and pancreatic islet content}

The increased insulin during the GTT could be explained by alterations in insulin release and/or in insulin removal. The mice fed a cafeteria diet demonstrated overall increased glucose-stimulated insulin secretion (GSIS; Fig. 3A) and increased total insulin content (Fig. 3B). The insulin secretion was increased even after normalization by total insulin content (Fig. 3C).

\section{Cafeteria diet-mediated effect on insulin clearance in mice}

Although the increased insulin secretion could at least partially explain the rapid and severe increase in insulinemia during the GTT, it was not sufficient for explaining the slower decay after reaching the peak. The cafeteria diet inhibited insulin clearance in mice, as evidenced by the insulin clearance test (Fig. 4A) and reduced insulin decay during the ITT (Fig. 4B), which resulted in increased insulin exposure during the test, as evidenced by an increase in the insulin AUC during the ITT (Fig. 4C).

\section{Cafeteria diet-mediated effect on IDE protein levels in mice}

To explain the reduced insulin clearance in mice fed a cafeteria diet, we investigated the IDE expression in several tissues. The IDE protein levels were reduced in the liver (Fig. 5A) and the skeletal muscle (Fig. 5B), were unchanged in adipose tissue (Fig. 5C), and were increased in the hypothalamus (Fig. 5D).

\section{Cafeteria diet-mediated effect on Ide mRNA levels and alternative splicing in mice}

Another factor that contributes to the control of insulin clearance is the alternative splicing of different Ide mRNA isoforms (Farris et al. 2005). Cafeteria diet-fed mice had lower total Ide mRNA levels and reduced higher- and lower-activity IDE alternative isoforms in the liver (Fig. 6A) and skeletal muscle (Fig. 6B), although it reduced the higher-activity isoform to a greater extent in both organs. The cafeteria diet had no effect on the adipose tissue

Published by Bioscientifica Ltd. 

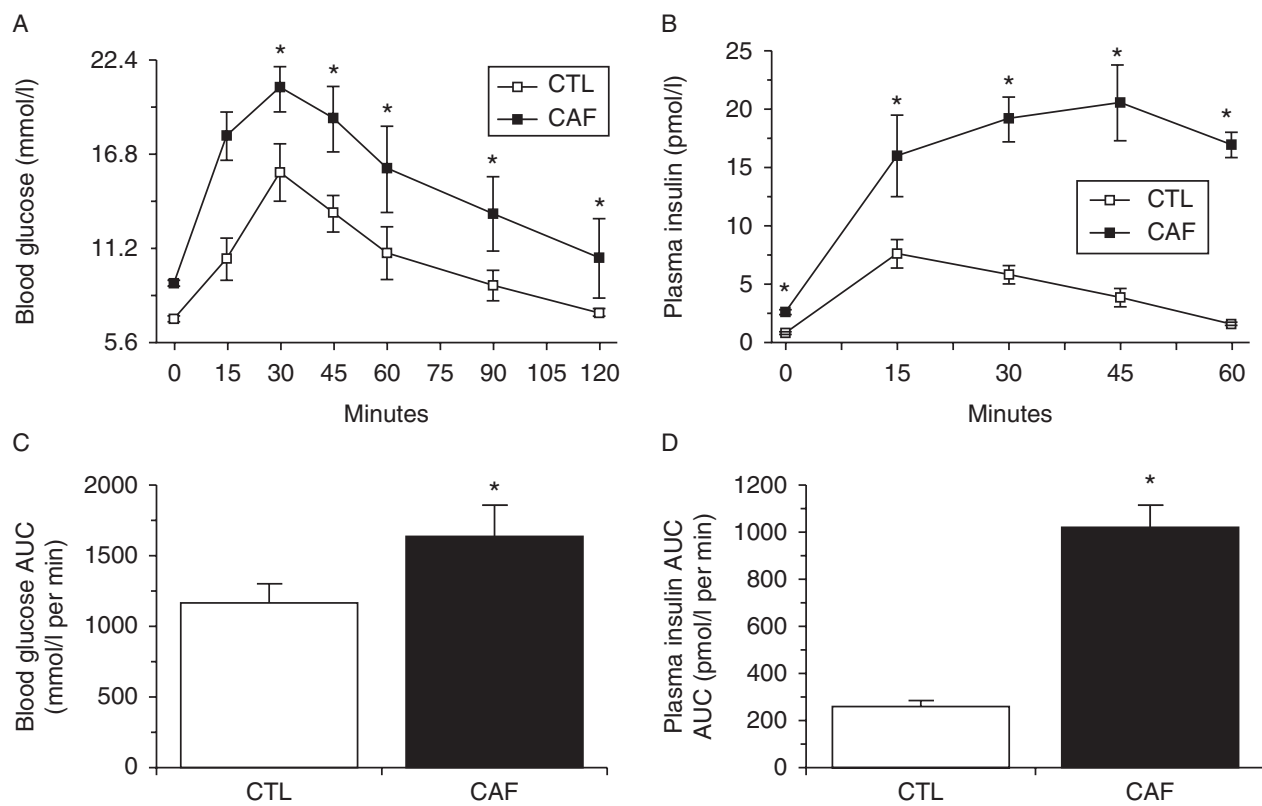

D

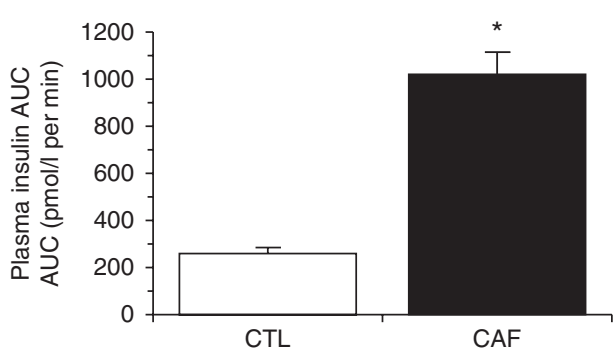

Figure 2

Cafeteria-diet-induced effect on glucose tolerance and insulin dynamics in mice. Intraperitoneal GTT test (A), and plasma glucose AUC during the GTT (B), plasma insulin during the GTT (C), and plasma insulin AUC during

the GTT (D) of the control (CTL) and cafeteria diet (CAF)-fed mice. The values are expressed as the mean \pm s.E.M., $n=6$. ${ }^{*} P \leq 0.05$ was considered significantly different from the control.

Ide mRNA levels (Fig. 6C), but it increased the total, high-, and low-activity Ide mRNA levels in the hypothalamus (Fig. 6D).

\section{Discussion}

Hyperglycemia is the primary variable associated with the diagnosis of type 2 diabetes, and perfect control of blood glucose by insulin depends on its plasma concentration (insulinemia) as well as its actions on peripheral tissues that cause glucose uptake (insulin sensitivity), thus lowering plasma glucose concentrations. Insulinemia is the result of a balance between the insulin produced and secreted by pancreatic islet $\beta$-cells and the rate that insulin is removed from plasma or insulin clearance (Duckworth et al. 1998).

Insulin clearance is fundamentally controlled by the liver, and $\sim 50 \%$ of secreted insulin is removed by the organ after the second passage through the portal vein (Butterfield 1970, Mittelman et al. 2000, Kotronen et al. 2008). Hepatic insulin removal and degradation is mainly controlled by a $130 \mathrm{kDa}$ zinc-metalloproteinase known as IDE (Duckworth 1988, Duckworth et al. 1998, Amata et al. 2009, Fernández-Gamba et al. 2009).

Although virtually every insulin-responsive cell expresses IDE, its main function in these organs is to

oppose insulin signaling by uncoupling insulin from the insulin receptor (IR), either by simply removing or partially or completely degrading insulin (Duckworth 1988, Duckworth et al. 1998, Amata et al. 2009). Therefore, it is not surprising that hepatic IDE inhibition increased insulin sensitivity coupled with increased IR activity (Kuo et al. 1991, Li et al. 2002, Leissring et al. 2010).

Thus, IDE expression and action accomplish a dual role in glucose homeostasis. On the one hand, IDE reduces insulinemia by increasing plasma insulin removal in the liver, and conversely, IDE reduces insulin sensitivity by rapidly interrupting the IR signaling pathway. Given the importance of insulin clearance and IDE expression to glucose homeostasis, it is not surprising that both are altered in obesity and type 2 diabetes.

Insulin clearance and IDE expression are reduced in type 2 diabetic individuals (Butterfield 1970, Groves et al. 2003, Karamohamed et al. 2003, Kotronen et al. 2007, 2008, Kwak et al. 2008, Rudovich et al. 2009, Slominskiı̌ et al. 2009) and in obese and diabetic rodents (McCarroll \& Buchanan 1973, Rabkin et al. 1986, Strömblad \& Björntorp 1986, Kotronen et al. 2008, Matveyenko et al. 2008, Rezende et al. 2012). Also, as previously mentioned, changes in insulin clearance are probably more relevant than the increase in insulin secretion to the higher insulinemia observed in obese individuals

Published by Bioscientifica Ltd. 

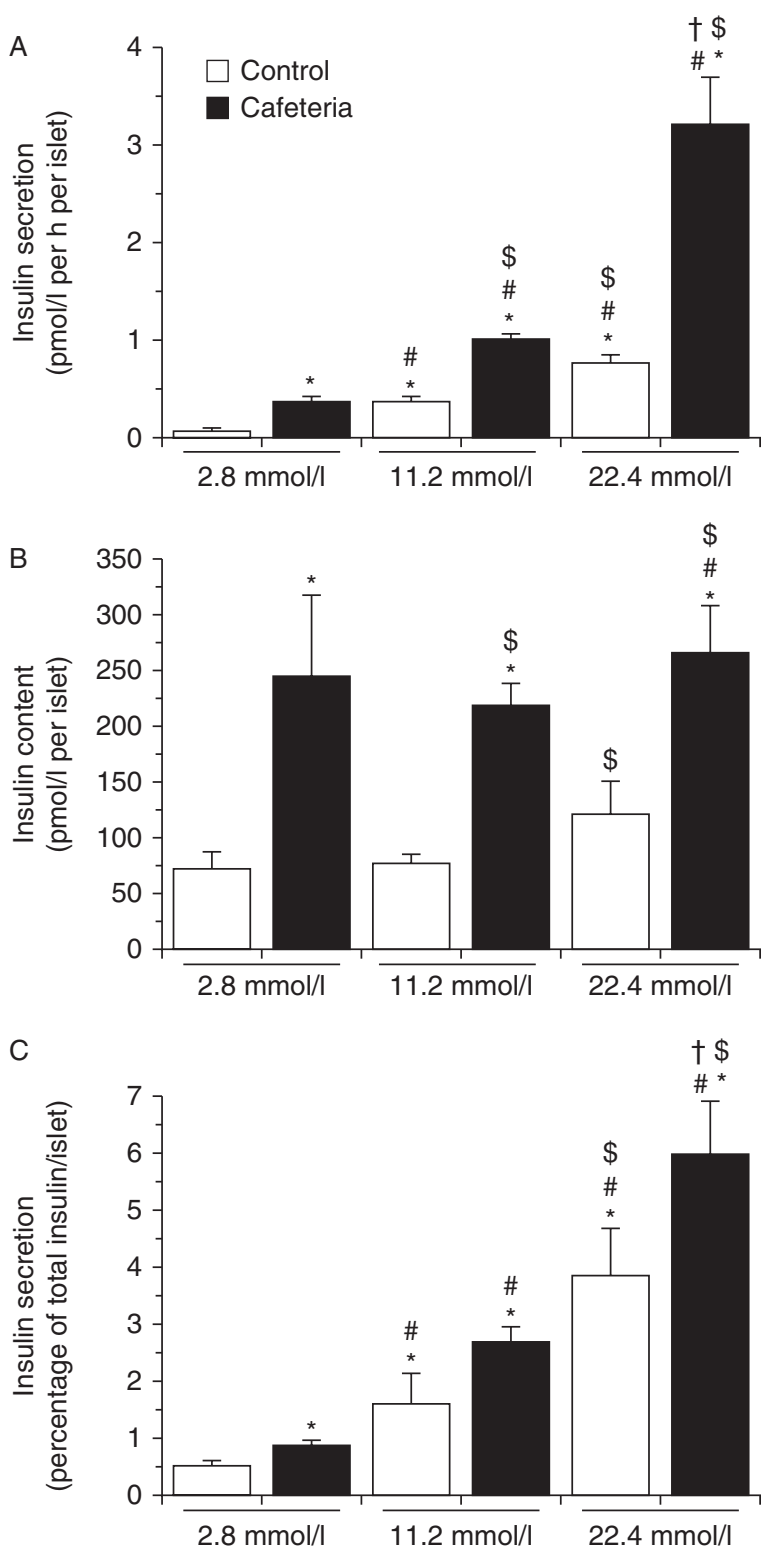

Figure 3

Cafeteria-diet-induced effect on insulin secretion and pancreatic islet content in mice. GSIS (A), total insulin content (B), and secreted insulin as a fraction of total insulin content $(C)$ in sub-stimulatory $(2.8 \mathrm{mmol} / \mathrm{l})$, stimulatory $(11.2 \mathrm{mmol} / \mathrm{l})$, and supra-stimulatory $(16.7 \mathrm{mmol} / \mathrm{l})$ glucose concentrations from isolated pancreatic islets that were assessed ex vivo from control (CTL) and cafeteria diet (CAF)-fed mice. The values are expressed as the mean \pm s.E.M., $n=6$. ${ }^{*} P \leq 0.05$ significantly different from the control 2.8 value, ${ }^{\#} P \leq 0.05$ significantly different from the respective control value, ${ }^{\$} P \leq 0.05$ significantly different from the control 11.2 value, and ${ }^{\dagger} P \leq 0.05$ significantly different from the control 22.4 value.

(Erdmann et al. 2008, 2009) and are highly heritable (Guo et al. 2012) with the highest correlation with insulinemia (Goodarzi et al. 2011).

The drawbacks of these studies are that most rodent obesity models involve an altered genetic background, such as $o b / o b$ mice, or are diet-induced. However, lipid supplementation of food does not correlate well with actual human Western feeding habits and is also less palatable, thus reducing food intake by the mice (Rothwell $\&$ Stock 1979).

In this sense, the cafeteria diet is a better model for studying glucose homeostasis in rodents because this diet more closely resembles actual Western society feeding habits, is still able to induce obesity, and is more palatable, which increases overall food intake (Sclafani \& Springer 1976, Rothwell \& Stock 1979, Prada et al. 2005). We
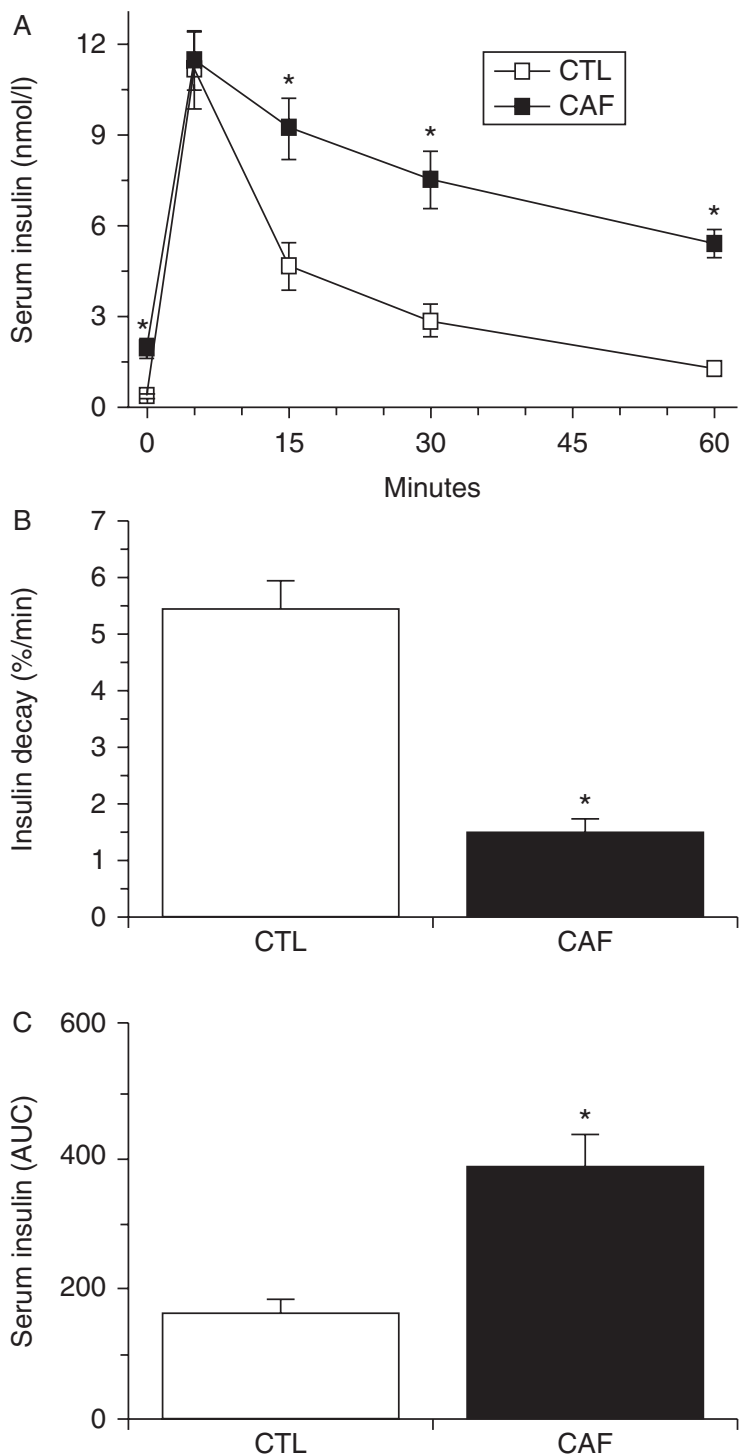

Figure 4

Cafeteria-diet-induced effect on insulin clearance in mice. Insulin clearance test (A), insulin decay rate during ITT (B), and insulin AUC during ITT (C) of control (CTL) and cafeteria diet (CAF)-fed mice. The values are expressed as the mean \pm s.E.M., $n=6$. ${ }^{*} P \leq 0.05$ significantly different from the control.

Published by Bioscientifica Ltd. 
A

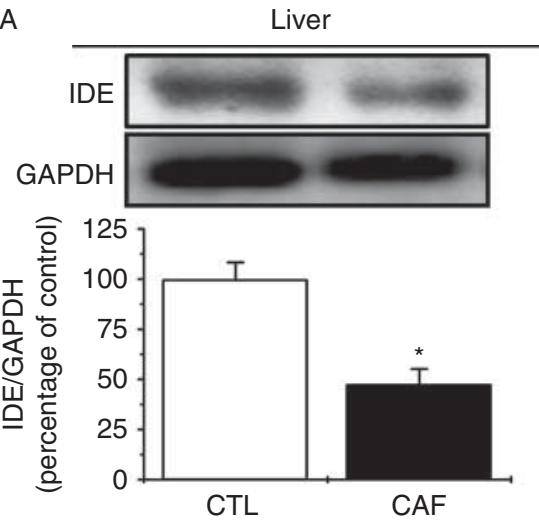

C
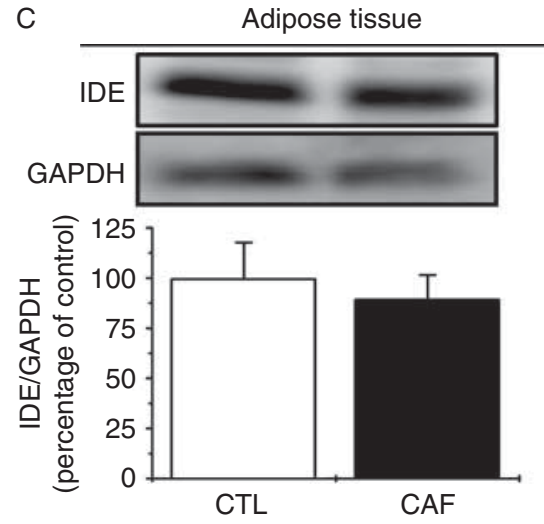

B

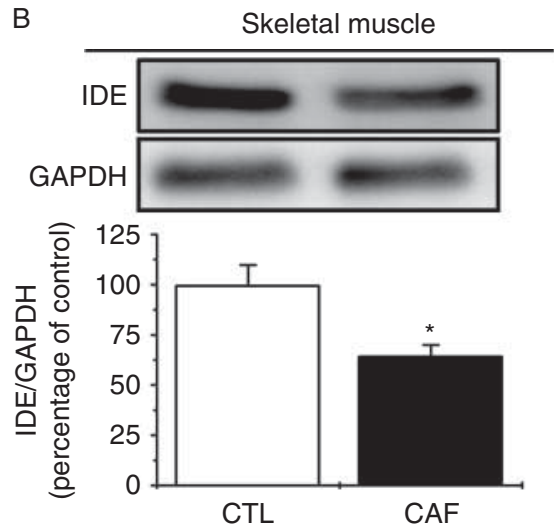

D

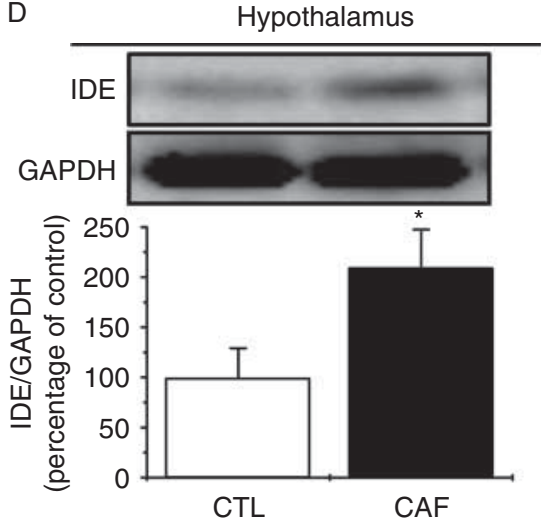

Figure 5

Cafeteria-diet-induced effect on IDE protein levels in mice. IDE protein levels in liver extracts (A), gastrocnemius muscle (B), visceral adipose tissue (C), and hypothalamus (D) from control (CTL) and cafeteria diet

determined that 8 weeks of cafeteria diet feeding in mice increased body weight, fat pad weight, triglycerides (TGs), and non-esterified fatty acids (NEFAs) (Table 1), most probably because of the increased overall food intake that is associated with increased calorie, lipid, and carbohydrate intake (Table 1). These changes were followed by increased glycemia (Table 1), insulin resistance (Fig. 1), glucose intolerance (Fig. 2), insulin secretion (Fig. 3), and reduced insulin clearance (Fig. 4).

Insulin resistance is a well-described feature of obese mice that is usually associated with reduced IR-AKT pathway activity, which is the canonical signaling pathway in most insulin-responsive organs, such as the liver, skeletal muscle, and adipose tissue (Rezende et al. 2012). However, the increase in insulin content and secretion from pancreatic islets involve changes in calcium influx in the pancreatic islets of cafeteria-dietfed rats (Vanzela et al. 2010).

Here, we show that reduced insulin clearance is associated with altered insulin sensitivity and secretion (Fig. 4),

(CAF)-fed mice. The values are expressed as the mean \pm s.E.M., $n=6$ ${ }^{*} P \leq 0.05$ was considered significantly different from the control.

most probably because of reduced hepatic IDE expression (Fig. 5). Furthermore, the cafeteria diet reduced high-activity rather than low-activity Ide mRNA, which effectively displaced the balance of high/low-activity IDE in favor of low-activity IDE in the liver and skeletal muscle (Fig. 6).

Despite not being particularly relevant to the insulin clearance process, other insulin-responsive tissues play a pivotal role in glucose homeostasis and expresses IDE, so we also evaluated IDE expression and alternative splicing in skeletal muscle, adipose tissue, and hypothalamus. IDE expression was also reduced in skeletal muscle, which is consistent with the pattern observed in liver and could possibly act as a safety mechanism to maintain some insulin effectiveness despite the insulin resistance, while IDE is unchanged in adipose tissue, an effect that has already been described in rats (Castell-Auví et al. 2012) despite the differences in duration of diet and methods for evaluation of insulin clearance.

The increased IDE expression in the hypothalamus probably helps to explain the hyperphagia in mice fed a

Published by Bioscientifica Ltd 
A

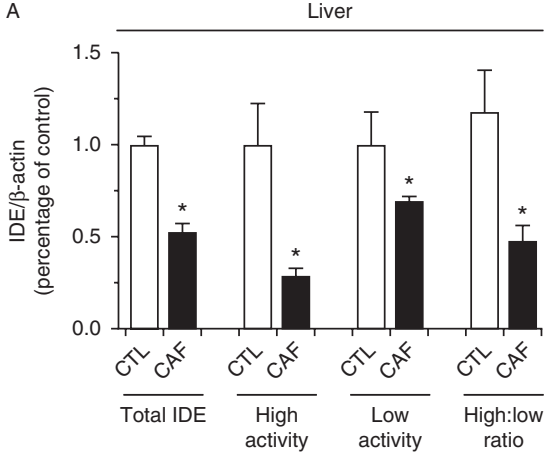

C

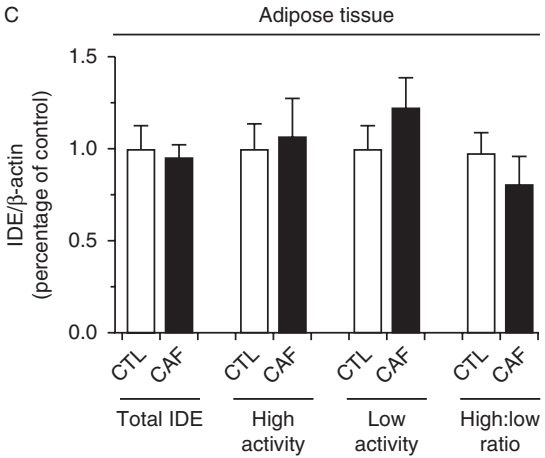

B
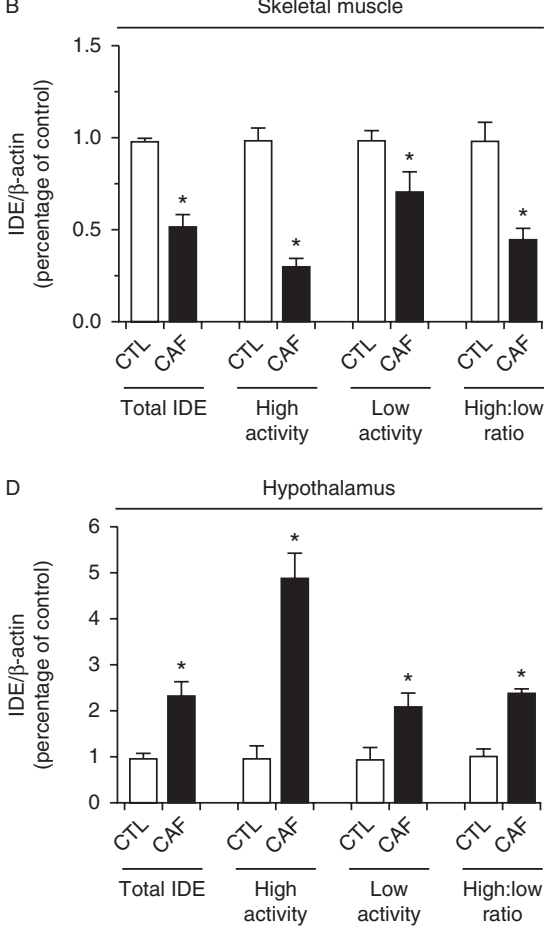

Figure 6

Cafeteria-diet-induced effect on Ide mRNA levels and alternative splicing in mice. Total, high-activity, and low-activity Ide mRNA transcript levels and ratios from liver $(A)$, gastrocnemius muscle $(B)$, visceral adipose tissue (C),

cafeteria diet, given that increased IDE expression would reduce the anorexigenic insulin effects on the hypothalamus (Porte et al. 2005), thus increasing the overall food intake.

The insulin clearance in cafeteria diet-fed rats has already been reported (Castell-Auví et al. 2012), but the discrepancies between our work and theirs might be attributed to a number of causes. First, that work involved rats while our study involved mice, and these species have differences in their lipid metabolism (Castell-Auví et al. 2012), which might help explain the differences between these two studies. Secondly, their experiment was lengthier and it has been already described that in dogs the time-course changes in insulin clearance do not follow a linear pattern and do vary according to the extent of the dietary intervention (Mittelman et al. 2000). Finally, in that study, the authors suggest increased IDE-mediated insulin clearance capability, as they found increased hepatic IDE activity. Although changes in IDE expression and activity are indeed the major contributing factors to alterations in insulin clearance, insulin clearance can also be affected by, for example, changes in renal blood flow or other physiological conditions (Duckworth 1988, and hypothalamus (D) of control (CTL) and cafeteria diet (CAF)-fed mice. The values expressed as the mean \pm S.E.M., $n=6$. ${ }^{*} P \leq 0.01$ was considered significantly different from the control value.

Duckworth et al. 1998). Hepatic IDE expression from cafeteria-diet-fed mice was most probably reduced because of the increased plasma TG and NEFA levels, as both of these inhibit insulin clearance and hepatic IDE expression (Wiesenthal et al. 1999, Balent et al. 2002, Hamel et al. 2003, Yoshii et al. 2006, Kotronen et al. 2007, 2008).

Another possibility is that cytokines, such as interleukin 6 (IL6), that are released by the oversized adipose tissue might control insulin clearance and hepatic IDE expression. Supporting this hypothesis is the evidence that ciliary neurotrophic factor (CNTF), a cytokine in the IL6 family, reduces insulin clearance and liver IDE expression in non-obese type 2 diabetic mice, and it also inhibits IDE expression and activity in hepatocytes in vitro (Rezende et al. 2012).

In conclusion, we demonstrated that in addition to increased insulin resistance and insulin secretion, cafeteria diet-induced obese mice also present with reduced insulin clearance that most probably occurs via hepatic IDE expression downregulation in these mice, which might explain the high correlation between reduced insulin clearance and both obesity and type 2 diabetes in humans, possibly as a consequence of the western feeding habits.

Published by Bioscientifica Ltd. 
Also, it indicates liver IDE to be a good candidate for a targeted therapeutic approach for obesity-induced type 2 diabetes.

\section{Declaration of interest}

The authors declare that there is no conflict of interest that could be perceived as prejudicing the impartiality of the research reported.

\section{Funding}

Fundação de Amparo à Pesquisa do Estado de São Paulo (FASEP), Conselho Nacional de Desenvolvimento Científico e Tecnológico (CNPq), and Instituto Nacional de Obesidade e Diabetes (INOD) provided financial support.

\section{Author contribution statement}

$P B, J M C$, and $L F R$ were responsible for the study design and $P B, J M C, A$ $O P, G J S$, and L F R for data acquisition and analysis. E M C, A O P, and A C B contributed to data analysis and interpretation. $P B, J M C$, and $L F R$ wrote the manuscript. E M C and A C B revised the manuscript. All the authors approved the final version.

\section{Acknowledgements}

The authors thank Marise M C Brunelli and Priscila O Marques for technical assistance and American Journal Experts, an English-speaking editing firm, for English revision.

\section{References}

Ahrén B, Thomaseth K \& Pacini G 2005 Reduced insulin clearance contributes to the increased insulin levels after administration of glucagon-like peptide 1 in mice. Diabetologia 48 2140-2146. (doi:10.1007/s00125-005-1915-z)

Amata O, Marino T, Russo N \& Toscano M 2009 Human insulin-degrading enzyme working mechanism. Journal of the American Chemical Society 131 14804-14811. (doi:10.1021/ja9037142)

Balent B, Goswami G, Goodloe G, Rogatsky E, Rauta O, Nezami R, Mints L, Angeletti RH \& Stein DT 2002 Acute elevation of NEFA causes hyperinsulinemia without effect on insulin secretion rate in healthy human subjects. Annals of the New York Academy of Sciences 967 535-543. (doi:10.1111/j.1749-6632.2002.tb04313.x)

Butterfield WJ 1970 Insulin clearance in nondiabetic and diabetic subjects. Panminerva Medica 12 233-235.

Castell-Auví A, Cedó L, Pallarès V, Blay M, Ardévol A \& Pinent M 2012 The effects of a cafeteria diet on insulin production and clearance in rats. British Journal of Nutrition 108 1155-1162. (doi:10.1017/ S0007114511006623)

Chandra J, Zhivotovsky B, Zaitsev S, Juntti-Berggren L, Berggren PO \& Orrenius S 2001 Role of apoptosis in pancreatic $\beta$-cell death in diabetes. Diabetes 50(Suppl 1) S44-S47. (doi:10.2337/diabetes.50.2007.S44)

Duckworth WC 1988 Insulin degradation: mechanisms, products, and significance. Endocrine Reviews 9 319-345. (doi:10.1210/edrv-9-3-319)

Duckworth WC, Bennett RG \& Hamel FG 1998 Insulin degradation: progress and potential. Endocrine Reviews 19 608-624. (doi:10.1210/ er.19.5.608)

Erdmann J, Kallabis B, Oppel U, Sypchenko O, Wagenpfeil S \& Schusdziarra V 2008 Development of hyperinsulinemia and insulin resistance during the early stage of weight gain. American Journal of
Physiology. Endocrinology and Metabolism 294 E568-E575. (doi:10.1152/ ajpendo.00560.2007)

Erdmann J, Mayr M, Oppel U, Sypchenko O, Wagenpfeil S \& Schusdziarra V 2009 Weight-dependent differential contribution of insulin secretion and clearance to hyperinsulinemia of obesity. Regulatory Peptides 152 1-7. (doi:10.1016/j.regpep.2008.10.008)

Farris W, Leissring MA, Hemming ML, Chang AY \& Selkoe DJ 2005 Alternative splicing of human insulin-degrading enzyme yields a novel isoform with a decreased ability to degrade insulin and amyloid $\beta$-protein. Biochemistry 44 6513-6525. (doi:10.1021/bi0476578)

Fernández-Gamba A, Leal MC, Morelli L \& Castaño EM 2009 Insulin-degrading enzyme: structure-function relationship and its possible roles in health and disease. Current Pharmaceutical Design 15 3644-3655. (doi:10.2174/138161209789271799)

Goodarzi MO, Cui J, Chen YD, Hsueh WA, Guo X \& Rotter JI 2011 Fasting insulin reflects heterogeneous physiological processes: role of insulin clearance. American Journal of Physiology. Endocrinology and Metabolism 301 E402-E408. (doi:10.1152/ajpendo.00013.2011)

Groves CJ, Wiltshire S, Smedley D, Owen KR, Frayling TM, Walker M, Hitman GA, Levy JC, O'Rahilly S, Menzel S et al. 2003 Association and haplotype analysis of the insulin-degrading enzyme (IDE) gene, a strong positional and biological candidate for type 2 diabetes susceptibility. Diabetes 52 1300-1305. (doi:10.2337/diabetes. 52.5.1300)

Guo X, Cui J, Jones MR, Haritunians T, Xiang AH, Chen YD, Taylor KD, Buchanan TA, Davis RC, Hsueh WA et al. 2012 Insulin clearance: confirmation as a highly heritable trait, and genome-wide linkage analysis. Diabetologia 55 2183-2192. (doi:10.1007/s00125-012-2577-2)

Hamel FG, Upward JL \& Bennett RG 2003 In vitro inhibition of insulindegrading enzyme by long-chain fatty acids and their coenzyme A thioesters. Endocrinology 144 2404-2408. (doi:10.1210/en.2002-0007)

Karamohamed S, Demissie S, Volcjak J, Liu C, Heard-Costa N, Liu J, Shoemaker CM, Panhuysen CI, Meigs JB, Wilson P et al. 2003 Polymorphisms in the insulin-degrading enzyme gene are associated with type 2 diabetes in men from the NHLBI Framingham Heart Study. Diabetes 52 1562-1567. (doi:10.2337/diabetes.52.6.1562)

Kim M, Hersh LB, Leissring MA, Ingelsson M, Matsui T, Farris W, Lu A Hyman BT, Selkoe DJ, Bertram L et al. 2007 Decreased catalytic activity of the insulin-degrading enzyme in chromosome 10-linked Alzheimer disease families. Journal of Biological Chemistry 282 7825-7832. (doi:10.1074/jbc.M609168200)

Kotronen A, Vehkavaara S, Seppälä-Lindroos A, Bergholm R \& Yki-Järvinen H 2007 Effect of liver fat on insulin clearance. American Journal of Physiology. Endocrinology and Metabolism 293 E1709-E1715. (doi:10.1152/ajpendo.00444.2007)

Kotronen A, Juurinen L, Tiikkainen M, Vehkavaara S \& Yki-Järvinen H 2008 Increased liver fat, impaired insulin clearance, and hepatic and adipose tissue insulin resistance in type 2 diabetes. Gastroenterology $\mathbf{1 3 5}$ 122-130. (doi:10.1053/j.gastro.2008.03.021)

Kuo WL, Gehm BD \& Rosner MR 1991 Regulation of insulin degradation: expression of an evolutionarily conserved insulin-degrading enzyme increases degradation via an intracellular pathway. Molecular Endocrinology 5 1467-1476. (doi:10.1210/mend-5-10-1467)

Kwak SH, Cho YM, Moon MK, Kim JH, Park BL, Cheong HS, Shin HD, Jang HC, Kim SY, Lee HK et al. 2008 Association of polymorphisms in the insulin-degrading enzyme gene with type 2 diabetes in the Korean population. Diabetes Research and Clinical Practice 79 284-290. (doi:10.1016/j.diabres.2007.08.017)

Leissring MA, Malito E, Hedouin S, Reinstatler L, Sahara T, Abdul-Hay SO, Choudhry S, Maharvi GM, Fauq AH, Huzarska M et al. 2010 Designed inhibitors of insulin-degrading enzyme regulate the catabolism and activity of insulin. PLOS ONE 5 e10504. (doi:10.1371/journal.pone. 0010504)

Li CZ, Zhang SH, Shu CD \& Ren W 2002 Relationship between insulindegrading enzyme activity and insulin sensitivity in cell model of insulin-resistance. Di Yi Jun Yi Da Xue Xue Bao 22 151-154. 
Matveyenko AV, Veldhuis JD \& Butler PC 2008 Adaptations in pulsatile insulin secretion, hepatic insulin clearance, and $\beta$-cell mass to age-related insulin resistance in rats. American Journal of Physiology. Endocrinology and Metabolism 295 E832-E841. (doi:10.1152/ajpendo. 90451.2008)

McCarroll AM \& Buchanan KD 1973 Insulin clearance by the isolated perfused livers of insulin deficient rats. Diabetologia 9 457-460. (doi:10.1007/BF00461688)

Mckeigue PM, Uusitupa M, Laitinen J, Mäkinen E \& Schwab U 1991 Insulin clearance and diabetes. Lancet 338 1270-1271. (doi:10.1016/ 0140-6736(91)92135-O)

Mittelman SD, Van Citters GW, Kim SP, Davis DA, Dea MK, Hamilton-Wessler M \& Bergman RN 2000 Longitudinal compensation for fat-induced insulin resistance includes reduced insulin clearance and enhanced $\beta$-cell response. Diabetes 49 2116-2125. (doi:10.2337/diabetes.49.12.2116)

Nijs HG, Radder JK, Frölich M \& Krans HM 1990 In vivo relationship between insulin clearance and action in healthy subjects and IDDM patients. Diabetes 39 333-339. (doi:10.2337/diabetes.39.3.333)

Pivovarova O, Gögebakan O, Pfeiffer AF \& Rudovich N 2009 Glucose inhibits the insulin-induced activation of the insulin-degrading enzyme in HepG2 cells. Diabetologia 52 1656-1664. (doi:10.1007/ s00125-009-1350-7)

Porte D, Baskin DG \& Schwartz MW 2005 Insulin signaling in the central nervous system: a critical role in metabolic homeostasis and disease from C. elegans to humans. Diabetes 54 1264-1276. (doi:10.2337/ diabetes.54.5.1264)

Prada PO, Zecchin HG, Gasparetti AL, Torsoni MA, Ueno M, Hirata AE, Corezola do Amaral ME, Höer NF, Boschero AC \& Saad MJ 2005 Western diet modulates insulin signaling, c-Jun N-terminal kinase activity, and insulin receptor substrate- $1^{\text {ser307 }}$ phosphorylation in a tissue-specific fashion. Endocrinology 146 1576-1587. (doi:10.1210/ en.2004-0767)

Rabkin R, Reaven GM \& Mondon CE 1986 Insulin metabolism by liver, muscle, and kidneys from spontaneously diabetic rats. American Journal of Physiology 250 E530-E537.

Rezende LF, Stoppiglia LF, Souza KL, Negro A, Langone F \& Boschero AC 2007 Ciliary neurotrophic factor promotes survival of neonatal rat islets via the BCL-2 anti-apoptotic pathway. Journal of Endocrinology 195 157-165. (doi:10.1677/JOE-07-0016)

Rezende LF, Vieira AS, Negro A, Langone F \& Boschero AC 2009 Ciliary neurotrophic factor (CNTF) signals through STAT3-SOCS3 pathway and protects rat pancreatic islets from cytokine-induced apoptosis. Cytokine 46 65-71. (doi:10.1016/j.cyto.2008.12.014)

Rezende LF, Santos GJ, Santos-Silva JC, Carneiro EM \& Boschero AC 2012 Ciliary neurotrophic factor (CNTF) protects non-obese Swiss mice against type 2 diabetes by increasing $\beta$ cell mass and reducing insulin clearance. Diabetologia 55 1495-1504. (doi:10.1007/ s00125-012-2493-5)

Rothwell NJ \& Stock MJ 1979 Regulation of energy balance in two models of reversible obesity in the rat. Journal of Comparative and Physiological Psychology 93 1024-1034. (doi:10.1037/h0077631)

Rudovich N, Pivovarova O, Fisher E, Fischer-Rosinsky A, Spranger J, Möhlig M, Schulze MB, Boeing H \& Pfeiffer AF 2009 Polymorphisms within insulin-degrading enzyme (IDE) gene determine insulin metabolism and risk of type 2 diabetes. Journal of Molecular Medicine 87 1145-1151. (doi:10.1007/s00109-009-0540-6)

Sampey BP, Vanhoose AM, Winfield HM, Freemerman AJ, Muehlbauer MJ, Fueger PT, Newgard CB \& Makowski L 2011 Cafeteria diet is a robust model of human metabolic syndrome with liver and adipose inflammation: comparison to high-fat diet. Obesity 19 1109-1117. (doi:10.1038/oby.2011.18)

Santos GJ, Oliveira CA, Boschero AC \& Rezende LF 2011 CNTF protects MIN6 cells against apoptosis induced by Alloxan and IL-1 $\beta$ through downregulation of the AMPK pathway. Cellular Signalling 23 1669-1676. (doi:10.1016/j.cellsig.2011.06.001)

Sclafani A \& Springer D 1976 Dietary obesity in adult rats: similarities to hypothalamic and human obesity syndromes. Physiology \& Behavior 17 461-471. (doi:10.1016/0031-9384(76)90109-8)

Slominskiı̌ PA, Pivovarova OV, Shadrina MI, Artem'eva AV, Pfaipffer FG, Rudovich NN, Agadzhanian SE, Pronin VS \& Limborskaia SA 2009 Association of insulinase gene polymorphisms with type 2 diabetes mellitus in patients from the Moscow population. Genetika 45 127-131.

Strömblad G \& Björntorp P 1986 Reduced hepatic insulin clearance in rats with dietary-induced obesity. Metabolism 35 323-327. (doi:10.1016/ 0026-0495(86)90148-4)

Valera Mora ME, Scarfone A, Calvani M, Greco AV \& Mingrone G 2003 Insulin clearance in obesity. Journal of the American College of Nutrition 22 487-493. (doi:10.1080/07315724.2003.10719326)

Vanzela EC, Ribeiro RA, de Oliveira CA, Rodrigues FB, Bonfleur ML, Carneiro EM, Souza KL \& Boschero AC 2010 Pregnancy restores insulin secretion from pancreatic islets in cafeteria diet-induced obese rats. American Journal of Physiology. Regulatory, Integrative and Comparative Physiology 298 R320-R328. (doi:10.1152/ajpregu.00256.2009)

Wiesenthal SR, Sandhu H, McCall RH, Tchipashvili V, Yoshii H, Polonsky K, Shi ZQ, Lewis GF, Mari A \& Giacca A 1999 Free fatty acids impair hepatic insulin extraction in vivo. Diabetes 48 766-774. (doi:10.2337/diabetes. 48.4.766)

Yoshii H, Lam TK, Gupta N, Goh T, Haber CA, Uchino H, Kim TT, Chong VZ, Shah K, Fantus IG et al. 2006 Effects of portal free fatty acid elevation on insulin clearance and hepatic glucose flux. American Journal of Physiology. Endocrinology and Metabolism 290 E1089-E1097. (doi:10.1152/ajpendo. 00306.2005)

Received in final form 5 August 2013

Accepted 19 August 2013

Accepted Preprint published online 19 August 2013 http://joe.endocrinology-journals.org

DOI: 10.1530/JOE-13-0177
() 2013 Society for Endocrinology Printed in Great Britain
Published by Bioscientifica Ltd 